Christian Efing, RWTH Aachen University, Germany

Bruno Arich-Gerz, RWTH Aachen University, Germany

Isa-Lou Sander, RWTH Aachen Uinversity, Germany

DOI:10.17951/Ismll.2021.45.1.1-6

\title{
Vielfalt des Gegenwartsdeutschen. Eine Einführung
}

\section{The Diversity of Contemporary German. An Introduction}

Der Begriff des Deutschen in seiner üblichen Singularform suggeriert eine sprachliche Homogenität, die es in der Realität nicht gibt. Hierfür muss man keine diachrone Perspektive einnehmen: Auch aus synchroner Sicht mit Blick nur auf das Gegenwartsdeutsche geht die Sprachrealität weit über die kodifizierte Standardvarietät als nur eine Varietät des Gegenwartsdeutschen hinaus. Die vorliegende Sondernummer der Lublin Studies in Modern Languages and Literature möchte diese Vielfalt des Gegenwartsdeutschen in all ihrer Heterogenität in den Blick nehmen und dabei exemplarisch verschiedenste Verwendungsformen und Variationen (Varietäten, Register, Entwicklungstendenzen...) beleuchten, die in der aktuellen linguistischen und sprachdidaktischen Debatte der Germanistik diskutiert werden. Bei der Zusammenstellung der Beiträge wurden verschiedene Perspektiven eingenommen: einerseits eine nach den traditionellen Dimensionen der Variation, andererseits nach den verschiedenen linguistischen Ebenen.

Als traditionelle Dimensionen der Variation setzt man gewöhnlich folgende an:

a) die diachrone Variation in der Zeit (Sprachstufen), die hier ausgeschlossen wird, da das Gegenwartsdeutsche im Fokus steht;

b) die diatopische Variation in Abhängigkeit vom Raum: Hierunter fallen vor allem Dialekte, Regiolekte, die verschiedenen nationalen Standardvarietäten in Deutschland, Österreich und der Schweiz oder auch Sprachinseln (Ein exemplarischer Beitrag zur nationalen Variation war angefragt, wurde allerdings leider so kurzfristig abgesagt, dass kein Ersatz mehr gefunden werden konnte.);

Christian Efing, Institut für Sprach- und Kommunikationswissenschaft, Rheinisch-Westfälische Technische Hochschule Aachen, Eilfschornsteinstraße 15, 52062 Aachen, Phone: 00492418096067, c.efing@isk.rwth-aachen.de, https://orcid.org/0000-0002-2488-6171

Bruno Arich-Gerz, Institut für Sprach- und Kommunikationswissenschaft, Rheinisch-Westfälische Technische Hochschule Aachen, Eilfschornsteinstraße 15, 52062 Aachen, b.arich@isk.rwth-aachen.de, https://orcid.org/0000-0002-5261-2856

Isa-Lou Sander, Institut für Sprach- und Kommunikationswissenschaft, Rheinisch-Westfälische Technische Hochschule Aachen, Eilfschornsteinstraße 15, 52062 Aachen, i.sander@isk.rwth-aachen.de, https://orcid.org/0000-0003-0544-0833 
c) die diastratische Variation in Abhängigkeit von der Schicht- oder Milieu-Zugehörigkeit: Hierunter fallen insbesondere Schichten- und Gruppensprachen (Soziolekte), aber auf die verschiedenen Spielarten der in dieser Sondernummer thematisierten Jugendsprachen oder ethnolektalen Sprechweisen;

d) die diaphasische Variation in Abhängigkeit von der Situation und Funktion (Register): Hierunter fallen etwa die Bildungs- oder die in dieser Sondernummer thematisierten Register der Fach- und der Berufssprache sowie der politische Sprachgebrauch.

e) Als fünfte Dimension wird neuerdings bisweilen sinnvollerweise eine diamediale Variation in Abhängigkeit von Medium und/oder Kommunikationsform angesetzt. Diese Dimension wird exemplarisch in einem Beitrag zum Online-Diskurs am Beispiel der Interaktion in der Blogosphäre.

Der Perspektive der verschiedenen linguistischen Ebenen wird durch folgende Strukturierung Rechnung getragen:

- Die lexikalische Ebene steht etwa in einem Beitrag zu Neologismen im Gegenwartsdeutschen im Vordergrund;

- Die grammatische Ebene wird in einem Beitrag zu Entwicklungstendenzen im Verbal- und syntaktischen Bereich in den Blick genommen;

- Die Text- und Diskursebene kommt etwa im bereits erwähnten Beitrag zum Online-Diskurs am Beispiel der Interaktion in der Blogosphäre zum Tragen.

Durch diese doppelte Perspektivierung werden im Rahmen der Sondernummer sowohl systemlinguistische wie auch sozio- und pragma- sowie textlinguistische Phänomene des Gegenwartsdeutschen thematisiert, sodass ein breites Spiegelbild oder zumindest ein Eindruck der Vielfalt des Gegenwartsdeutschen entsteht. Im Einzelnen sind die hier versammelten Beiträge wie folgt gruppiert und gehen auf folgende Schwerpunkte ein:

Einen arealen Schwerpunkt haben die Beiträge von Claudia Maria Riehl und Rahel Beyer (Deutsch als Minderheitensprache) und Robert Möller und Stephan Elspaß (Mehr als Dialekt-Relikte: Regionale Variation im Gegenwartsdeutschen). Die areale Vielfalt des Gegenwartsdeutschen wird von Möller und Elspaß in den Fokus gestellt. Anhand des Atlas zur deutschen Alltagssprache werden verschiedene Beispiele arealer Variation des Deutschen vor dem Hintergrund von nationaler und regionaler Verortbarkeit vorgestellt und diskutiert. Riehl und Beyer untersuchen in ihrem Beitrag die Rolle des Deutschen als Minderheitensprache und diskutieren Spezifika, Dynamiken und soziolinguistische Bedingungen von Varietäten des Deutschen im Bereich der Sprachinseln und Grenzminderheiten. Neben einem historischen Überblick werden außerdem die vielfältigen Sprachkontakt-Konstellationen der deutschen Sprachminderheiten in den Blick genommen.

Die soziolektale, funktionale und mediale Vielfalt des Gegenwartsdeutschen werden, mit unterschiedlichen Schwerpunktsetzungen, in den Beiträgen von Nils 
Bahlo und Sharon Lohse (Indexing Kiez - Zur Deethnisierung juventulektaler Stile), Thorsten Roelcke (Fachsprachliche Vielfalt im Gegenwartsdeutschen), IsaLou Sander (Berufssprache), Thomas Niehr (Politischer Sprachgebrauch) und Joanna Pędzisz (Rollen der Internetnutzer im Online-Diskurs am Beispiel der Interaktion in der Blogosphäre) behandelt. Bahlo und Lohse stellen in ihrem Beitrag den Sprachgebrauch Jugendlicher in den Fokus. Anhand von Gesprächsdaten von Jugendlichen ohne Migrationshintergrund wird untersucht, welche außersprachlichen Aspekte - unabhängig von der Ethnie der Sprecherinnen und Sprecher - den Sprachgebrauch von Jugendlichen beeinflussen und welche sprachlichen Merkmale durch das Ausprobieren und Übernehmen von ursprünglich ethnolektal geprägten Sprechweisen identifiziert werden können.

Roelcke behandelt in seinem Beitrag zur funktionalen Vielfalt den Aspekt der fachsprachlichen Vielfalt im Bereich beruflicher Kommunikation und diskutiert den Einfluss und den Stellenwert der zentralen Entwicklungstendenzen Differenzierung, Dezentralisierung und Dynamisierung. Der Beitrag von Sander ist ebenfalls im Kontext der beruflichen Kommunikation zu verorten. Hier liegt der Schwerpunkt auf der Vorstellung und Diskussion des Registers der Berufssprache, das sich als berufsfeldübergreifendes Register an den zentralen Kommunikationssituationen im Beruf und deren Funktionen orientiert und damit Anknüpfungspunkte für eine didaktische Nutzbarmachung bietet. Vor dem Hintergrund einer anderen Domäne des öffentlichen Sprachgebrauchs und seiner Erforschung, der Entwicklung der Politolinguistik, werden im Beitrag von Niehr Besonderheiten der politischen Kommunikation vorgestellt, diskutiert und hinsichtlich der Frage, wie diese Merkmale politischer Kommunikation methodisch untersucht werden können, eingeordnet.

Joanna Pędzisz widmet sich in ihrem mediale Aspekte fokussierenden Beitrag der Analyse von Internetnutzerinnen und -nutzern im Online-Diskurs. Am Beispiel der Blog-Interaktion werden entsprechende Rollenkonstellationen und Interaktionsprofile vorgestellt und diskutiert.

Auf gegenwärtige Entwicklungen des Deutschen auf den Ebenen von Lexik und Grammatik gehen schließlich die Beiträge von Christian Efing und Hilke Elsen ein. Der Bereich der Lexik steht im Beitrag von Elsen im Fokus. Neben grundlegenden Forschungsstrategien im Bereich „,neue Wörter“ werden hier auch aktuelle Entwicklungen in Theorie und Methodik der Neologismenforschung vorgestellt. Efing wendet sich in seinem Beitrag der Variation und Vielfalt in der Grammatik des Gegenwartsdeutschen zu und erläutert anhand von ausgewählten Entwicklungstendenzen Unterschiede zwischen gesprochener und geschriebener Gegenwartssprache.

Aachen, im März 2021 
The concept of German as language, customarily used in its singular form, suggests a linguistic homogeneity that does not in fact exist. It will not be necessary to resort to a diachronic perspective to prove this: even from a synchronic perspective, and even if one looks only at contemporary German, there are no two opinions about the fact that today's language reality goes far beyond the standard variety. In fact, the codified standard is just one in a multitude of contemporary German(s).

This special issue of Lublin Studies in Modern Languages and Literature examines the diversity of contemporary German in all its heterogeneity and highlights, by way of example, the various forms of use and variation (varieties, registers, developments and tendencies...) that are being discussed in present-day linguistic and language-didactic debates. Different perspectives have been adopted in the contributions compiled here as one can focus on the traditional dimensions of variation or, alternatively, on the established axis of (different) linguistic levels.

Traditional dimensions of variation include

a) diachronic variation in time (language periods), which is excluded here because the focus is on contemporary German;

b) diatopic variation marked by spatial (or areal) distribution. This includes dialects, 'regiolects', the various national standard varieties in Germany, Austria and Switzerland as well as Sprachinseln (language islands);

c) diastratic variation depending on class or milieu affiliation. This comprises class and group languages (sociolects) as well as varieties of youth language or ethnolect speech patterns which will be discussed in the issue;

d) diaphasic variation depending on specific situations and functions (register). This includes, for example, educational language or the registers of technical and job-related language as well as political language use, all to be discussed in this issue;

e) diamedial variation as a recently emerging fifth dimension, characterized by media as a determining factor and resulting in specific communication forms. This dimension will be exemplified in a contribution on online discourse(s) and interaction in the blogosphere.

The range of linguistic levels complements the subdivision in traditional dimensions. In this issue,

- the lexical level is foregrounded in a contribution on neologisms in contemporary German;

- the grammatical level is considered in a chapter on developmental tendencies in the verbal and syntactic area;

- the textual and discourse level comes into play in the contribution on online discourse and interaction in the blogosphere. 
Arranged along the (double) perspectives of traditional dimensions and linguistic levels, the chapters of this issue thus address system-linguistic as well as socio-, pragma- and text-linguistic phenomena of contemporary German. As such, they cover a wide range and provide an impression of the diversity of contemporary German.

The chapters and their respective focal points can be grouped as follows:

The contributions by Claudia Maria Riehl \& Rahel Beyer (German as a Minority Language) and Robert Möller \& Stephan Elspaß (More than Dialect Relics: Regional Variation in Contemporary German) have an areal focus. Using the Atlas zur deutschen Alltagssprache (AdA), Möller \& Elspaß present examples of areal variation in German and discuss them against the background of national and regional locality. Riehl \& Beyer examine the role of German as a minority language by discussing the characteristics, dynamics and sociolinguistic conditions as well as the historical backgrounds of varieties of German in language islands and among border minorities, and by taking into account the diverse languagecontact constellations of German-language minorities.

The sociolectal, functional and medial diversity of contemporary German is addressed, with different emphases, in the chapters by Nils Bahlo \& Sharon Lohse (Indexing Kiez - Deethnization of Adolescent Speechstyles), Thorsten Roelcke (Diversity of Languages for Special Purposes in Contemporary German), IsaLou Sander (Job-Related Language), Thomas Niehr (Political Language Use), and Joanna Pędzisz (Roles of Internet Users in Online Discourse on Example of Interaction in the Blogosphere). Bahlo \& Lohse focus focuses on the language use of young people. On the basis of conversation data of non-migrant adolescents, they inspect extra-linguistic aspects - independent of the ethnicity of the speakers - and the degree to which they influence the language use of adolescents. Another aim is the identification of the linguistic features that emerge in the juveniles' trying out and adopting ethnolect ways of speaking.

Roelcke's chapter on functional diversity deals with the aspect of linguistic diversity in the field of professional communication; more exactly, it discusses the influence and significance of the key developmental tendencies differentiation, decentralization and dynamization. Sander's contribution also deals with communication in professional contexts. Her focus is on the presentation and discussion of the register of job-related language. As a cross-professional register, it is employed in - and must meet the requirements of - central communication situations and their functions, which in turn can be made fruitful for didactic utilization. Pivoting on another domain of public language use and its study, Niehr discusses specific features of political communication and classifies them with regard to the question of how they can be studied methodically.

Joanna Pędzisz provides an analysis of Internet users in online discourse. Using the example of blog interaction, she investigates the corresponding role constellations and interaction profiles. 
The chapters by Christian Efing and Hilke Elsen, finally, deal with current developments in German on the levels of lexis and grammar. Lexis is the focus of Elsen's contribution which presents basic research strategies in the field of "new words" as well as recent developments in the theory and methodology of neologism research. Efing's contribution turns to variation and diversity in the grammar of contemporary German and explains differences between spoken and written contemporary language on the basis of selected current trends.

Aachen, March 2021 